\title{
DIFFERENCES BETWEEN HEALTH EDUCATION WITH VIDEO AND COMIC DIGITAL THROUGH WHATSAPP TO KNOWLEDGE HIV/AIDS IN JUNIOR HIGH SCHOOL 1 SUMBERPUCUNG
}

\author{
Della Salsa D'azzuri ${ }^{1 *}$, Tri Nurhudi Sasono ${ }^{1}$, Nia Agustiningsih ${ }^{1}$ \\ Afiliasi
}

1. Program Studi Keperawatan Program Sarjana STIKes Kepanjen Malang

Dikirim 7 Februari 2020

Direvisi 21 Oktober 2020

Diterima 28 Oktober 2020

Dipublikasikan 30 November 2020

*Corresponding author

Email :

dellasalsa74@gmail.com

\begin{abstract}
ABSTRAK
Pendidikan kesehatan tentang HIV/AIDS sangat penting diberikan untuk remaja untuk menghindari penularan HIV/AIDS. Penelitian ini bertujuan untuk mengetahui perbedaan pendidikan kesehatan menggunakan media video dan media komik digital melalui media sosial whatsapp terhadap pengetahuan HIV/AIDS pada remaja di SMP Negeri 1 Sumberpucung. Desain penelitian Quasi Experimental dengan jumlah responden sebanyak 36 responden yang dibagi menjadi 2 kelompok. Teknik pengambilan sampel menggunakan simple random sampling. Pengambilan data menggunakan lembar kuisioner. Uji statistik menggunakan Uji T berpasangan untuk mengetahui perbedaan pengetahuan sebelum dan sesudah diberikan pendidikan kesehatan dan Uji T tidak berpasangan untuk mengetahui keefektifan antara media video dan media komik digital. Hasil penelitian menggunakan Uji T berpasangan menunjukkan bahwa ada perbedaan pengetahuan HIV/AIDS pada remaja setelah diberikan pendidikan kesehatan menggunakan media video dan media komik digital melalui WA dengan peningkatan rata-rata kelompok media video 1,61 sedangkan kelompok media komik digital 0,5. Dari hasil Uji T tidak berpasangan didapatkan hasil nilai $P$ value sebesar 0,022 atau $p$ value $<0,05$. Dari hasil diatas media video lebih efektif meningkatkan pengetahuan remaja daripada media komik digital sehingga media video dapat digunakan untuk media edukasi bagi tenaga kesehatan maupun media pembelajaran di sekolah.
\end{abstract}

Kata Kunci : HIV/AIDS, Video, Komik Digital, WhatsApp, Remaja, Pendidikan Kesehatan, Pengetahuan.

\begin{abstract}
Health education about HIV / AIDS is very important given to adolescence to reduce transmission of HIV /AIDS. This study aimed to determine the differences in health education using video and digital comics through Whatsapp on the knowledge of HIV / AIDS in adolescents at Junior High School 1 Sumberpucung. This study used a Quasi Experimental with 36 respondents divided into 18 respondents for the video group and 18 respondents for the digital comic group. The sample collection technique was obtained using Simple Random Sampling. Data was collected a questioner sheet. Statistical tests use paired T-tests to measure differences in knowledge before and after education is given to each group and unpaired T-tests are used to determine the effectiveness of video and digital comic media. The results of the study using the paired T-Test showed that there were differences in knowledge of HIV / AIDS in adolescents after being given health education using video and digital comic through WA with the result of an increase in the average digital video group 1.61 while the digital comic group 0, 5 From the results of the unpaired T-Test, P-value of 0.022 was obtained. The result showed that video more effective to improve the knowledge of the adolescence than digital comics so that video can be used to the media in the provision of education health or can also be the media of learning in school.
\end{abstract}

Keywords : HIV/AIDS, Video, digital comics, WhatsApp, adolescence, health education, knowledge.

Sitasi jurnal :

D'azzuri DS, Sasono TN, Agustiningsih N. 2020. Differences Between Health Education With Video And Comic Digital Through Whatsapp To Knowledge HIV/AIDS In Junior High School 1 Sumberpucung. Jurnal Ilmu Keperawatan 8(2): 68-73 Doi: 10.21776/ub.jik.2020.008.02.1 


\section{PENDAHULUAN}

Pendidikan kesehatan tentang HIV/AIDS sangat penting diberikan untuk remaja. Saat ini, prevalensi penyakit HIV/AIDS semakin meningkat ke seluruh penjuru dunia khususnya bagi remaja. Pada saat usia remaja, mereka akan mengalami perubahan fisik, emosional maupun perkembangan seksualnya. Oleh karena itu, dengan timbulnya perkembangan seksual remaja akan mempunyai rasa keingintahuan tentang seksual menjadi lebih besar dan dorongan untuk melakukan hubungan seksual juga menjadi meningkat. Dengan adanya hal itu, remaja akan berisiko terhadap terinfeksinya penyakit HIV/AIDS (Wibowo, 2014).

Data prevalensi terinfeksi virus HIV yang terjadi di dunia sebanyak 34,5 juta jiwa diantaranya 17,8 juta jiwa penderita perempuan dan 16,7 juta jiwa penderita laki-laki. Dari jumlah penderita HIV tersebut, terdapat penderita yang berusia kurang dari 15 tahun sebanyak 2,1 juta jiwa (UNAIDS, 2017). Di Indonesia, prevalensi kasus HIV positif berdasarkan kelompok umur, pada tahun 2018 yaitu usia 5-14 tahun sebanyak 1\%, usia 15-19 tahun sebanyak 3,1\%, sedangkan prevalensi kasus AIDS berdasarkan kelompok umur yaitu usia 5-14 tahun sebanyak 1,1\%, usia 15-19 tahun sebanyak 2,8\% (Kementerian Kesehatan Republik Indonesia, 2018). Adapun di Kabupaten Malang, menurut Komisi Perlindungan AIDS (KPA) jumlah laporan pada tahun 2018 sebanyak 2.497 jiwa yang terinfeksi HIV/AIDS diantaranya yaitu terdapat usia remaja sebanyak 198 jiwa. Pada tahun 2019, di Puskesmas Sumberpucung mempunyai kasus HIV/AIDS sebanyak 102 ODHA. Dari jumlah 102 ODHA, terdapat 2 orang penderita HIV/ AIDS yang berumur 25 tahun dengan riwayat menjadi pekerja seks komersial (PSK) 1 orang sejak berumur 17 tahun dan 1 orang tertular penyakit HIV/AIDS dari suaminya pada umur 18 tahun.

Pada saat usia remaja, banyak remaja yang mempunyai keinginan untuk melakukan suatu hal yang baru, merasa bosan dengan rutinitas yang dilakukannya, dan mulai melakukan aktivitas secara berkelompok sehingga mereka bisa mengikuti trend yang sedang dilakukan oleh teman-temannya. Dengan adanya hal itu, remaja sangat dipengaruhi oleh lingkungan, perkembangan IPTEK, dan media sosial maupun media massa sehingga remaja dapat mudah mencari informasi sendiri menggunakan smartphone yang mereka miliki.
Di Indonesia kasus terinfeksi HIV/AIDS terjadi pada usia produktif yaitu sekitar umur 13-24 tahun, hal itu dikarenakan kurangnya pemaparan informasi mengenai HIV/AIDS pada remaja (Wulandari, 2018). Selain itu, pesatnya pengaruh dari penggunaan media sosial juga dapat memberikan dampak buruk pada pergaulan remaja SMP yang saat ini sudah mulai bebas pergaulannya seperti orang dewasa dan juga kurangnya informasi mengenai pendidikan kesehatan mengenai HIV/AIDS di remaja SMP (Kurniawati, 2019). Salah satu upaya yang dapat dilakukan untuk mengurangi penyebaran terjadinya HIV/AIDS pada remaja adalah dengan memberikan pendidikan kesehatan mengenai HIV/AIDS sedini mungkin pada remaja.

Pendidikan kesehatan atau biasa disebut dengan penyuluhan kesehatan adalah suatu kegiatan yang bertujuan untuk menyampaikan informasi agar mendapatkan pengetahuan tentang kesehatan. Pendidikan kesehatan dapat dipahami bagi sasaran jika menggunakan suatu media dalam penyampaian informasinya (Afrimal, 2016).Saatini mediayang paling mudah digunakan adalah media sosial yaitu whatsApp (WA). Saat ini media sosial merupakan media yang paling efektif untuk memberikan pendidikan kesehatan dimana media sosial terdiri dari WA, Facebook, dan lain-lain. Selain media sosial ada media cetak yang bisa disebarkan melalui handphone seperti komik digital yang biasanya hanya disebarkan melalui buku tetapi sekarang ada komik yang berbentuk digital yang disebarkan melalui media sosial contohnya melalui WA. Selain itu, aplikasi WA juga dapat mengirimkan video.

Beberapa hasil penelitian yang menggunakan media WA mengatakan bahwa metode dengan menggunakan media WA mempunyai pengaruh lebih besar terhadap tingkat pengetahuan dibandingkan dengan menggunakan media lainnya contohnya media booklet (Fitri, 2019; Nugroho, 2019). Sedangkan menurut penelitian yang menggunakan media komik digital, komik digital sangat efektif digunakan untuk media pembelajaran (Riwanto, 2018; Styaningsih \& Nuryadi, 2016). Adapun menurut penelitian yang menggunakan media video yang disebarkan melalui handphone lebih efektif dibandingkan menggunakan media yang lainnya (Sulandjari, 2018).

Berdasarkan beberapa penelitian diatas bahwa media video digital dan komik digital melalui WA sama- 
sama efektif untuk pendidikan kesehatan daripada media lainnya sehingga penelitian ini bertujuan mencari perbedaan pendidikan kesehatan dengan menggunakan media video dan komik digital melalui WA terhadap pengetahuan HIV/AIDS pada remaja di SMPN 1 Sumberpucung.

\section{METODE}

Penelitian ini menggunakan desain penelitian quasi experiment design. Quasi Experiment Design mempunyai kelompok kontrol, tetapi tidak sepenuhnya berfungsi untuk mengontrol variabel lain yang digunakan mempengaruhi pelaksaan eksperimen. Dari pembagian kelompok tersebut, kelompok eksperimen diberi perlakuan dengan media komik digital dan kelompok kontrol diberikan media video.

Sampel yang digunakan pada penelitian ini sejumlah 36 siswa yang ditentukan menggunakan teknik simple random sampling. Adapun kriteria inklusi dalam penelitian ini yaitu remaja yang bersedia menjadi responden, remaja yang mengikuti semua kegiatan dalam penelitian mulai dari pretest hingga posttest dan remaja yang memiliki handphone sendiri sedangkan kriteria eksklusinya yaitu remaja yang sedang mengikuti kegiatan yang ditugaskan oleh sekolah dan yang tidak hadir dalam penelitian.

Instrumen yang digunakan dalam penelitian ini adalah lembar kuisioner berupa checklist dengan menggunakan skala guttman. Instrument ini digunakan untuk mengukur pengetahuan HIV/AIDS pada remaja. Instrument ini awalnya berupa kisi-kisi soal kemudian soal dari kisi-kisi itu dilakukan uji validitas di sekolah lain yang setara dan pada kelas yang sama yang diisi oleh 20 responden. Peneliti membuat 15 butir soal uji instrument berupa soal pilihan benar dan salah. Setelah dilakukan uji validitas dan reliabilitas didapatkan hanya 10 soal yang layak digunakan intsrumen sesuai dengan hasil uji validitasnya.

Penelitian ini dilakukan dengan pemilihan subjek secara acak yang dibagi mejadi 2 kelompok yaitu kelompok video dan kelompok komik digital, kemudian menjelaskan tujuan penelitian kepada responden, dan memberikan informed consent. Selanjutnya peneliti membagikan lembar kuisioner untuk dilakukan pretest. Kemudian peneliti membuat group WhatsApp (WA) untuk memberikan intervensi selama 3 hari dengan mengirimkan berupa video pada group WA kelompok video dan komik pada group WA kelompok komik. Hari berikutnya peneliti membagikan lembar kuisioner untuk dilakukan posttest. Data yang terkumpul kemudian di tabulasikan untuk proses analisis data dan interpretasi.

Analisis data yang digunakan pada penelitian ini adalah analisis univariat yaitu dengan cara mendistribusikan karakteristik responden meliputi usia, jenis kelamin dan sumber informasi. Selain itu juga menyajikan data hasil pengetahuan HIV/ AIDS pada remaja sebelum (pretest) dan sesudah (posttest) diberikan pendidikan kesehatan dengan menggunakan media video dan media komik digital dengan menggunakan uji statistik paired t test.

Analisis bivariat untuk mengetahui perbedaan pendidikan kesehatan menggunakan media video dan media komik digital melalui WA terhadap pengetahuan HIV/AIDS pada remaja. Perhitungan statistik untuk data penelitian menggunakan sistem komputerisasi dengan uji independent $t$ test.

Penelitian ini dilakukan sesuai dengan etik penelitian dan telah dinyatakan layak etik oleh Komisi Etik Penelitian Kesehatan Sekolah Tinggi Ilmu Kesehatan Kepanjen dengan No. 012/S.Ket/KEPK/ STIKesKPJ/XII/2019.

\section{HASIL}

\section{Karakteristik Responden}

Tabel 1. menunjukkan bahwa sebagian besar responden dari kelompok video dan kelompok komik digital berumur 14 tahun yaitu masing-masing 11 orang $(61,1 \%)$ dan 7 orang (38,9\%). Pada kelompok video digital sebagian besar responden berjenis kelamin laki-laki dan kelompok komik digital berjenis kelamin perempuan yaitu sebanyak 10 orang (55,6\%). Kemudian responden pada kelompok video dan kelompok komik digital yang belum pernah mendapatkan informasi mengenai HIV/AIDS sebanyak 13 orang $(72,2 \%)$ dan yang sudah pernah sebanyak 5 orang $(27,8 \%)$. 
Tabel 1 : Distribusi frekuensi responden

\begin{tabular}{|c|c|c|c|c|c|}
\hline \multirow[t]{2}{*}{ Variabel } & \multirow[t]{2}{*}{ Kategori } & \multicolumn{2}{|c|}{$\begin{array}{l}\text { Kelompok Video } \\
\qquad(\mathrm{N}=18)\end{array}$} & \multicolumn{2}{|c|}{$\begin{array}{l}\text { Kelompok Komik Digital } \\
\qquad(\mathrm{N}=18)\end{array}$} \\
\hline & & $\mathrm{N}$ & $\%$ & $\mathrm{~N}$ & $\%$ \\
\hline \multirow[t]{4}{*}{ Usia } & 13 tahun & 3 & 16,7 & 6 & 33,3 \\
\hline & 14 tahun & 11 & 61,1 & 7 & 38,9 \\
\hline & 15 tahun & 4 & 22,2 & 5 & 27,8 \\
\hline & Total & 18 & 100 & 18 & 100 \\
\hline \multirow[t]{3}{*}{ Jenis Kelamin } & Laki-laki & 10 & 55,6 & 8 & 44,4 \\
\hline & Perempuan & 8 & 44,4 & 10 & 55,6 \\
\hline & Total & 18 & 100 & 18 & 100 \\
\hline \multirow[t]{3}{*}{ Sumber Informasi } & Tidak Pernah & 13 & 72,2 & 13 & 72,2 \\
\hline & Pernah & 5 & 27,8 & 5 & 27,8 \\
\hline & Total & 18 & 100 & 18 & 100 \\
\hline
\end{tabular}

Sumber : Data Primer Kuisioner, Desember 2019

Tabel 2 : Deskripsi pengetahuan responden tentang HIV/AIDS

\begin{tabular}{ccccc}
\hline Keterangan & \multicolumn{2}{c}{ Kelompok video } & \multicolumn{2}{c}{ Kelompok komik digital } \\
& $\begin{array}{c}\text { Pretest } \\
\text { Pengetahuan }\end{array}$ & $\begin{array}{c}\text { Posttest } \\
\text { Pengetahuan }\end{array}$ & $\begin{array}{c}\text { Pretest } \\
\text { Pengetahuan }\end{array}$ & $\begin{array}{c}\text { Posttest } \\
\text { Pengetahuan }\end{array}$ \\
\cline { 2 - 5 } Rata-rata & 6,83 & 8,44 & 6,89 & 7,39 \\
SD & 1,505 & 1,381 & 1,023 & 1,243 \\
Minimum & 4 & 6 & 5 & 5 \\
Maksimum & 9 & 11 & 9 & 10 \\
\hline
\end{tabular}

Sumber : Data Primer Kuisioner, Desember 2019

\section{Pengetahuan Remaja tentang HIV/AIDS}

Tabel 2. menunjukkan nilai rata-rata pretest pengetahuan pada kelompok video dan kelompok komik digital tidak jauh beda yaitu 6,83 dan 6,89 artinya lebih tinggi pada kelompok komik digital. Hasil rata-rata posttest pengetahuan pada kelompok video lebih tinggi dibandingkan dengan kelompok komik digital yaitu 8,44 dan 7,39.

Analisis uji rata-rata Pengetahuan Remaja pretest dan posttest yang mendapatkan pendidikan kesehatan dengan media video

Berdasarkan analisis data nilai p-value didapatkan sebesar 0,000. Nilai p-value < 0,05 maka hasilnya Ho ditolak, yang artinya terdapat perbedaan rata-rata pengetahuan remaja antara sebelum dan sesudah diberikan pendidikan kesehatan tentang HIV/AIDS di SMP Negeri 1 Sumberpucung, sehingga disimpulkan bahwa pengetahuan pada kelompok remaja yang mendapatkan pendidikan kesehatan menggunakan media video meningkat setelah dilakukan pendidikan kesehatan melalui WA.
Analisis uji rata-rata Pengetahuan Remaja pretest dan posttest yang mendapatkan pendidikan kesehatan dengan media komik digital

Berdasarkan analisis data nilai p-value $<0,05$ yaitu 0,008 maka hasilnya Ho juga ditolak, yang diartikan bahwa terdapat perbedaan rata-rata pengetahuan remaja antara sebelum dan sesudah diberikan pendidikan kesehatan tentang HIV/AIDS di SMP Negeri 1 Sumberpucung, sehingga disimpulkan bahwa pengetahuan pada kelompok remaja yang mendapatkan pendidikan kesehatan menggunakan media komik digital meningkat setelah dilakukan pendidikan kesehatan melalui WA.

Analisis uji beda efektivitas pendidikan kesehatan menggunakan media video dan media komik digital melalui WA terhadap pengetahuan remaja

Hasil penelitian pada uji beda efektivitas pendidikan kesehatan menggunakan media video dan media komik digital melalui WA terhadap pengetahuan remaja dengan menggunakan data uji selisih rata-rata skor dari pretest dan posttest dari setiap kelompok. Uji beda selisih dalam penelitian ini menggunakan uji 
independent t test didapatkan nilai $p$-value $<0,05$ yaitu 0,022 maka hasilnya yaitu Ho ditolak yang diartikan terdapat beda efektivitas dari pemberian pendidikan kesehatan menggunakan media video dan media komik digital melalui WA dalam meningkatkan pengetahuan remaja tentang HIV/AIDS. Kelompok media video mendapatkan selisih rata-rata pengetahuan yang lebih tinggi daripada kelompok media komik digital.

\section{PEMBAHASAN}

Berdasarkan hasil penelitian terdapat perbedaan besar jumlah jenis kelamin pada penelitian ini dipengaruhi oleh cara pengambilan sampel yaitu dengan simple random sampling, dan peneliti juga tidak melakukan penelitian berdasarkan jenis kelamin. Kemudian berdasarkan jenis usia, pada kelompok video dan kelompok komik digital sebagian besar responden berusia 14 tahun, hal ini disebabkan usia mayoritas kelas 1 dan 2 berkisar pada usia tersebut.

\section{Analisis uji rata-rata Pengetahuan Remaja pretest dan posttest yang mendapatkan pendidikan kesehatan dengan media video}

Berdasarkan penelitian yang dilakukan pada kelompok video menunjukkan bahwa ada peningkatan hasil pengetahuan antara sebelum dan sesudah dilakukan pendidikan kesehatan melalui WA, peningkatan pengetahuan dapat dilihat dari nilai pretest 6,83 dan posttest 8,44. Kemudian didapatkan nilai $p$-value $=0,000$ dengan nilai $p<0,05$ maka Ho ditolak yang artinya ada beda rata-rata antara nilai sebelum dan sesudah dilakukan pendidikan kesehatan melalui WA dan media video ini dapat membantu unuk meningkatkan pengetahuan. Hasil penelitian ini sejalan dengan penelitian Kristianto, dkk (2017) yang melakukan penyuluhan kesehatan dengan menggunakan media video melalui WA didapatkan adanya peningkatan pengetahuan yang memperoleh hasil $p$-value $=0,0001$ yang artinya media video melalui WA merupakan salah satu media yang efektif digunakan dalam pendidikan kesehatan untuk meningkatkan derajat kesehatan.

\section{Analisis uji rata-rata Pengetahuan Remaja pretest dan posttest yang mendapatkan pendidikan kesehatan dengan media komik digital}

Berdasarkan penelitian yang dilakukan pada kelompok komik digital menunjukkan bahwa ada peningkatan hasil pengetahuan antara sebelum dan sesudah dilakukan pendidikan kesehatan melalui WA, peningkatanpengetahuan dapatdilihatdarinilaipretest 6,89 dan posttest 7,39. Kemudian didapatkan nilai $\mathrm{p}$-value $=0,008$ dengan nilai $\mathrm{p}<0,05$ maka Ho ditolak yang artinya ada beda rata-rata antara nilai sebelum dan sesudah dilakukan pendidikan kesehatan. Hasil penelitian ini sejalan dengan penelitian yang dilakukan (Mariyaningsih, 2018) yang melakukan pendidikan kesehatan menggunakan media komik yang dapat meningkatkan pengetahuan siswa dengan mendapatkan hasil $p$-value $=0,000$ yang artinya media komik juga efektif dalam meningkatkan pengetahuan siswa.

\section{Efektivitas perbedaan antara media video dan media komik digital}

Berdasarkan penelitian ini, hasil analisis data membuktikan adanya perbedaan pengaruh antara kelompok media video dan kelompok media komik digital. Selisih nilai rata-rata antara pretest dan posttest pada kelompok media video digital sebanyak 1,61 sedangkan pada kelompok komik digital 0,5 serta nilai $p$-value yang didapatkan sebesar $0,022(\mathrm{p}<0,05)$ sehingga Ha ada perbedaan yang artinya terdapat perbedaan pendidikan kesehatan menggunakan media video dan media komik digital melalui WA. Kemudian dengan melihat perbedaan nilai selisih ratarata dari kelompok video dan kelompok komik digital didapatkan nilai selisih rata-rata media video lebih tinggi dibandingkan media komik digital. Oleh karena itu, pendidikan kesehatan menggunakan media video melalui WA lebih efektif digunakan untuk pendidikan kesehatan daripada media komik digital. Hal ini didukung oleh penelitian (Norazizah, 2016) yang mengatakan bahwa media video dapat menyajikan apa yang tidak dapat dialami langsung oleh responden karena media video terdiri dari audio dan visual yang dapat menghadirkan situasi nyata dari informasi yang disampaikan serta menimbulkan kesan yang mendalam. Selain itu juga dapat mempercepat proses belajar dengan bantuan media audiovisual mampu meningkatkan kecerdasan dan mengubah sikap pasif menjadi aktif.

\section{KESIMPULAN}

Kesimpulan dari penelitian ini adalah terdapat perbedaan tingkat pengetahuan remaja tentang HIV/ 
AIDS menggunakan media video digital dan media komik digital. Dari hasil tersebut, didapatkan juga media video digital lebih efektif digunakan untuk

\section{DAFTAR PUSTAKA}

Afrimal,A. S. A. (2016). Artikel / Jurnal Efektifitas Media Slide Sound Terhadap Tingkat Pengetahuan Hiv / Aids Kelas X Di Sma Pgri 3 Padang Tahun 2015. Penelitian Keperawatan Komunitas. 1-11.

Fitri, Dkk. (2019). Perbandingan Diabetes Self Management Education Metode Ceramah Menggunakan Booklet Dengan Metode Group Whatsapp Terhadap Self Care Behaviorpasien Diabetes Mellitus. Jurnal Kesehatan Komunitas, 4(3), 126-131. Https://Doi.Org/10.25311/ Keskom.Vol4.Iss3.294

Kementerian Kesehatan Republik Indonesia. (2018). Laporan Provinsi Jawa Timur Riskesdas 2018. Jakarta.

Kurniawati, H. F. (2019). Gambaran Penggunaan Internet Dalam Pencarian Informasi Tentang Hiv Dan Aids Pada Remaja. Jurnal Kebidanan, 8(1), 27. Https://Doi.Org/10.26714/Jk.8.1.2019.27-37

Mariyaningsih, D. (2018). Pengaruh Pendidikan Kesehatan Dengan Media Komik Terhadap Pengetahuan Dan Sikap Siswi Tentang Tablet Tambah Darah Dan Anemia Di Smp Negeri 2 Sragen.

Norazizah, R. (2016). Efektivitas Promosi Kesehatan Melalui Media Power Point Dan Video Terhadap pendidikan kesehatan pada remaja sehingga media video digital juga dapat digunakan sebagai media pembelajaran bagi tempat penelitian.

Tingkat Pengetahuan Kader Tentang Kanker Serviks Di Wilayah Kerja Puskesmas Mlati I.

Nugroho, Dkk. (2019). Pengaruh Edukasi Menstruasi Melalui Whatsapp Terhadap SelfCare Dismenore Pada Remaja Putri Sma Di Kota Bengkulu. 7(1), 88-93.

Riwanto, Dkk. (2018). Efektivitas Penggunaan Media Komik Digital (Cartoon Story Maker) Dalam Pembelajran Tema Selalu Berhemat Energi. Jurnal Pancar, 2(1).

Styaningsih, H. A., \& Nuryadi, M. H. (2016). Pengaruh Penggunaan Media Komik Digital Terhadap Upaya Penegakan Ham. 3(November), 129140.

Sulandjari, R. (2018). efektivitas literasi media (video) dari handphone mahasiswa pada minat berwirausaha makanan berbahan baku lele berorientasi B2SA masyarakat desa karangsari. Jurnal Egaliter, 1(2).

Wibowo, dkk. (2014). Tingkat Pengetahuan Remaja Tentang Hiv / Aids Di Kota Pekalongan. 11-21.

Wulandari, F. (2018). Pengaruh Pendidikan Kesehatan Melalui Booklet Terhadap Tingkat Pengetahuan Dan Sikap Remaja Dalam Pencegahan Dini HIV/ AIDS Di SMPN 23 Kota Surakarta. Universitas Muhammadiyah Surakarta. 